\title{
Needle Biopsy of Kidney
}

National Cancer Institute

\section{Source}

National Cancer Institute. Needle Biopsy of Kidney. NCI Thesaurus. Code C51764.

Removal of tissue from the kidney, for microscopic examination, using a needle. 